carries on. Questions are sometimes asked as to whether this is all worth while, and both in Congress and elsewhere, occasionally questions are put as to whether there is an actual money return for the funds which are expended in this work. It is hardly a fair test to apply, but the work that the Bureau of Foreign and Domestic Commerce has done will stand even this test. The letters from American firms who have been helped by the Bureau and who have quite spontaneously expressed their gratitude run into thousands. The sales of American merchandise in foreign countries as a direct result of the trade opportunities that are pointed out to American manufacturers by the Bureau have from year to year run well into millions of dollars. There have been instances of single sales that have run up into seven figures. This tangible result is not counted by the Bureau as the main result of its work, however. The Burealy officials believe that they have accomplished more by keeping American manufacturers awake to the importance of foreign trade and of doing it on the best ethical and technical basis than by means of this trade opportunity service. The settling of commercial disputes between traders in the United States and traders abroad has been a line of service carried on by the Bureau which has produced remarkably good results. The good that was done by the American commercial attaché in Australia in the trying years between 1914 and 1917 , before we entered the war, can never be calculated in dollars and cents. It was largely through the efforts of this representative of the Department of Commerce that American national good will in commerce was preserved there in spite of vigorous propaganda against the United States and its commercial methods. There . is no calculating in dollars and cents the value to American foreign trade in general when individual American concerns are aided by the Bureau to change their export methods so as to conform to the best practice.

We are prone in this country to view our own Government as rendering less assistance to trade than the governments of foreign countries. I am inclined to believe that this is characteristic of business men everywhere. In England for years it has been the practice of business men to knock the Board of Trade, the organization in England which corresponds to our Department of Commerce. In Germany the average manufacturer has always professed to despise government assistance. Here we have pointed to Germany and England as examples of how governments help trade. In England they point to us and to Germany as examples of how government helps trade. In Germany they have pointed to England and to the United States as examples of how government helps trade. So it goes.

When I went to Germany to take part in an investigation of the German pottery industry I went somewhat with the idea that I was going to find government subsidies to trade, which, with starvation wages, had been proclaimed before our Ways and Means Committee as the reason for German success in foreign trade. I made a point of talking with German manufacturers on the subject of the help they received from the government. I never found a manufacturer who would concede that the government was helping hini at all-instead he was usually growling at the burden of government taxation and interference. In this very industry that you gentlemen are engaged in in this country there is a disposition to point to Germany and to say that the German government is directly subsidizing the German manufacturing industries and that there is no hope of competing with German manufacturers under these conditions. The tradition that the government was backing all the German trading and manufacturing companies, and that to this was due the success of German industry in the world market, is a dangerous and regrettable thing. There are too many American manufacturers who without knowing the facts are inclined to cry, "Wolf, wolf," and demand government support or government protection on that false basis. In
British countries in the course of the liquidation of German concerns there has been a direct effort to trace out the extent of government assistance. To date I have seen nothing as a result of the work of liquidators that has been at all convincing evidence that German success abroad was due to direct government help. In fact, one of the British official liquidators at Hong Kong who made a deliberate attempt to ferret out evidence of government participation in German trade in that colony admitted frankly that the books and papers of the liquidated concerns gave reason rather for the contrary conclusion. We do not know all the facts about the German methods of commercial penetration, and possibly we never shall. We do know that the German government has shown a very sympathetic attitude toward the big commercial interests, has encouraged them in many ways, has given material encouragement to German shipping, and has worked with pretty definite governmental commercial policies, all in the interest of increased national efficiency. Admit all this, however, and yet on the whole we have got to admit further that German commercial and manufacturing success has been chiefly attributable to energy and careful planning in private organization. It will be a bad thing for the American manufacturer to fool himself into abject dependence on government support in getting and holding his business. The American manufacturer in the long run, just like the manufacturer in any other country, must organize better, produce better, and sell better than his competitors. I am not going to enter into any discussion of the merits of government protection and government subsidies, each of which may have its place in carefully organized governmental commercial policy, but I do wish to mention the need of a cultivation of a spirit of self-reliance and confidence in manufacturing and selling ability among the American manufacturers. Our Government can help a manufacturer in a variety of ways. I have to-night pointed out some of the ways in which the Bureau of Foreign and Domestic Commerce can render assistance. I think that in the field covered by the work of the Bureau our Government has done as much and as effective work as any foreign government. Times and circumstances have been greatly changed as a result of the war. Other governments are reorganizing and preparing to spend large sums in promoting their interests in after-war trade. From all that we know of the past and present attitude of our own Government I should say that we have no reason to believe that our Government will not expand its own service, give it variety and new lines of activity, just as much as the national interests require. We must not look to the Government to do the business for us, but at the same time we cannot afford to ignore or underestimate the value of what the Government is prepared to do and is actually doing.

\section{OUR PUBLICATIONS AND THEIR BEARING ON THE CHEMICAL INDUSTRY}

By O. P. Hopkins

Chief, Editorial Division, Bureau of Foreign and Domestic Commerce

The recent wonderful development of the chemical industry in this country has awakened in our chemists a desire to be better informed on the relations of the American industry to that of the rest of the world. They have a vision of a permanent and self-contained industry here at home, but they now realize that this vision will never be made a reality by ignoring what is going on in other countries, by making themselves believe that the future is assured no matter what plans, what commercial campaigns, what trade tendencies may be attracting attention elsewhere. They realize, in short, that the time has come for the chemical industry, along with almost every other industry we have, to accustom itself to a much broader view of affairs, to adopt a world point of view.

This has led to the suggestion that the industry is now ready 
to take a more serious interest than heretofore in foreign-trade statistics and information in general bearing on the exportation and importation of chemicals, raw materials, and machinery and apparatus. The members of this Section will suspect at once that the suggestion comes from Dr. Herty. and Dr. Hesse, and such suspicions are well founded. In response to their suggestion I am going to call attention to the wealth of material published by the Bureau of Foreign and Domestic Commerce and offer a few practical suggestions for making use of it.

I suppose the interested members may be divided into two classes: Those who intend to make a practical commercial use of our data, and those who simply wish to keep up with the times, to be well informed on all matters pertaining to their calling, whether or not it will ever mean dollars and cents to them. Both groups will be kept in mind as far as possible.

Our Bureau is the original source of all statistics relating to American foreign trade, and its figures are issued monthly, quarterly, annually, and bi-annually. If a chemist or chemical manufacturer wishes to keep his finger on the pulse of our foreign trade as it rises and falls from month to month, he will turn to the "Monthly Summary;" if he wishes to follow in considerable detail the ebb and flow of imports only, he will study the "Quarterly Statement of Imported Merchandise Entered for Consumption;;" if he wishes to review the trade for a whole year as compared with previous years, he will examine the annual "Commerce and Navigation;" and if he wishes to go rather deeply into our trade with any particular country or countries, he will turn to "Trade of the United States with the World," which has been published every two years, but in the future will be published yearly.

\section{MONTHLY STATISTICS}

The "Monthly Summary" shows imports and exports by quantities and values for the latest month compared with the corresponding month of the previous year and also for the months of the current fiscal or calendar year ended with that month. For instance, the May number this year gave the trade for May as compared with May of last year, and also the total trade of the eleven months ended with May as contrasted with similar periods in 1917 and 1916 . In June the total was shown for the twelve months of the fiscal year contrasted with the two fiscal years immediately preceding, although in much less detail than will be shown in the annual report when it is issued. In July, however, in addition to the statistics for the month, there is shown the total for the seven months of the calendar year, which plan will be followed until the calendar year is finished, when periods of the fiscal year will again be considered.

Countries of origin and destination are shown only for articles moving in great quantities, and this rule unfortunately affects a great many articles in which the chemical manufacturer is interested. Just recently, however, it was decided to show the destination of our rapidly growing dyestuff exports and this feature has attracted considerable attention. Countries are also shown for some of the oils, naval stores, rubber, and the most important metals and ores.

As already stated, these figures enable a manufacturer to keep his finger on the pulse of our foreign trade, but they are just the bald statistical facts. They are not analyzed in any way. Analysis is left to the reader, perhaps to a greater extent than is necessary. At any rate it will be a wise plan for the chemist who wishes to get the most out of the figures to devise some plan of his own for separating out the material in which he is most interested. An outline for a compact little continuous table can easily be made and filled in from month to month, for one article or for some logical group of articles. Percentages of increases or decreases can be shown conspicuously in a number of different ways. Personally, I think a graph is the most satisfactory way of tracing movements of this kind, and it is my understanding that chemists are pretty keen at devising things of that sort.

\section{QUARTERLY STATISTICS OF IMPORTS}

The quarterly statistical statement relates only to imported merchandise entered for consumption in the United States. It is designed primarily for Congress and such government officials as may be interested in tariff legislation, for it gives not only the rate of duty for each item imported, but the total amount of duty collected as well. It is not likely that many members of the AMERICAN CHEMICAL SOCIETY are interested in the tariff statisties, but there is one feature of the quarterly statistics that should not be overlooked. The classes are subdivided to a much greater extent than in the "Monthly Summary." For instance, under the heading "Chemicals" in the "Monthly Summary" only two acids are named, oxalic and carbolic, whereas in the Quarterly there are thirty-two. That is an important feature, and one that is very commonly overlooked. The Quarterly, however, does not indicate origin in any case, nor is any comparison made with quarters of previous years. The imports are simply set down in some detail for a quarter of the fiscal year, alongside the preceding quarters of the same year. If it happens to be the first quarter, then no. comparison is attempted. If a person decides that he wants to keep his finger on the pulse of the import trade in a certain line of chemicals and finds that there is not adequate information. available in the "Monthly Summary," he can turn to the Quarterly and if he wants to go to the trouble of keeping a graph he will soon be able to trace the important developments in his line over a considerable period. For the busy man it ought to be possible to assign the work of keeping the graph or compiling a continuous table to a secretary or clerk. It would take very little time in any event.

\section{ANNUAL, STATISTICS BY ARTICLES}

The annual "Commerce and Navigation of the United States" is an imposing volume of nearly a thousand large pages of solid statistics. It is so formidable in appearance that many people hesitate to trust themselves to find in it the information they wish, and prefer to write in to the Bureau and have us look up the data. But it really isn't complicated at all. For the chemist, who is accustomed to prying into all sorts of mystifying. secrets, this book ought to be a very simple matter. I am sure it has proved simple to any who have tried it.

The three annual tables of prime interest to the chemical industries are No. 3, "Imports of Merchandise," by articles and countries; No, 5, "Exports of Domestic Merchandise," by articles and countries; and No. 9, "Imported Merchandise Entered for Consumption," by articles.

Two features of the tables "Imports of Merchandise" and "Exports of Merchandise" make the volume invaluable to anyone who wishes to make a serious study of our foreign trade. In the first place, all of the countries of origin and countries of destination are given for each article-there are no baffling "other countries" to contend with. In the second place, a comparison is afforded with each of the four years immediately preceding the last. Another feature that deserves mention is the recapitulation under each article showing the imports or exports by continents.

The list of articles in these two annual tables is about the same as that in the "Monthly Summary," but not as detailed as in the Quarterly. Quantities are shown wherever possible, and values in all cases. The tables are used for the most part in making studies of the origin and destination of the goods that enter into our foreign trade. If the chemist wishes to find out where our quebracho imports originate, he turns to the index for the page he wishes and soon comes upon the quantity and value of the imports for each contributing country for the last five years.

The third annual table mentioned as being of interest to the chemist is No. 9, which is an annual compilation of the quarterly statistics already described. It has the same advantageous 
feature of great detail and the same disadvantages of not furnishing a comparison with preceding periods and of not indicating the origin of the imports. If all the countries of origin were shown for all the articles given and comparisons made with preceding years, this table alone would be larger than the entire voltume now devoted to the annual statistics. Possibly the day will come when such a table will be issued, but the demand from many industrics will have to be much stronger than it is to-day.

There is also included in this volume a table showing our exports of foreign merchandise, that is, our re-exports of foreign goods. It may occasionally happen that items in that table will interest the chemist. There are twenty-one other tables that need not be described. A good index prevents any confusion that might otherwise result from gathering so many tables under one cover.

\section{STUDIES OF COUNTRIES}

The "Commerce and Navigation" is intended to facilitate commodity studies, and is not well suited for studies of countries. If a chemical manufacturer wished to study our trade in caustic soda he would find his information in "Commerce and Navigation;" but if he wished to survey our chemical trade with Argentina, say, he would be almost obliged to turn to our "Trade of the United States with the World," in which each country is taken up separately and its import and export trade with the United States shown in detail by articles.

This work has been published every two years in two volumes, one for imports and one for exports. There is no particular reason why it should not be published every year, and from now on it is going to be.

The statistics are for fiscal years and comparison is made with returns for the year immediately preceding the last.

\section{COMMERCE REPORTS}

For the chemist who wishes to have something more than just the statistics of our foreign trade in chemicals there is available the Bureau's daily "Commerce Reports." which relies for its material upon the American consuls, traveling special agents, commercial attachés, trade commissioners, and the experts in the Washington office.

The reports from these various sources cover practically all phases of foreign trade, but for the most part may be said to aim at promoting the sale of American goods in foreign markets. A fair proportion of them bear directly on markets for chemicals and allied materials and products, although there are not as many on heavy chemicals as there will be when the manufacturers of those lines go in for foreign trade on a large scale. When the demand for information increases, the supply will increase. Reports on the markets for such lines as medicinal preparations and pharmaceutical supplies are much more numerous, while on such allied products as paper there is no end of information.

The reports vary widely in character. There may be one on a pressing temporary shortage of caustic soda in Brazil, while another may review at some length the conditions that govern the use of caustic soda in that country, with an opinion as to future developments that will affect the market. Others may throw light on the subject of packing chemicals for certain markets or on tariff regulations.

Sources of raw materials also receive attention and not a few reports are devoted to the appearance of new products in the various countries and to new manufacturing processes.

Actual opportunities for selling goods or forming business connections are featured in a separate department, usually made up as the last page of the paper. Millions of dollars' worth of American goods have been sold through these trade opportunities, and a goodly share has been chemicals or allied products.

But of course this paper appears every day and if a busy man merely glances over it, and perhaps misses a number occasionally, he will not gain more than a very general impression of what is going on in the foreign trade. If he wishes to follow developments more carefully and get practical results, he must devise some way of getting together the material in which he is most interested and keeping it easily available. It is at that point that many manufacturers, chemists among them probably, decide not to see it through.

It happens that I do not know a chemical manufacturer with a working method for extracting the good metal from this mass of ore, but I do know of a system devised by one of our largest hosiery manufacturers. He, the president of the concern himself, spends two or three minutes each morning in marking material in Commerce Reports for filing. His stenographer then clips the marked passages and pastes them on colored paper. White paper is used for reports on hosiery, yellow for reports on miscellaneous wearing apparel, and green for any reports on general conditions that might possibly have a bearing on the demand for hosiery. These are filed by countries and take up very little room. When he wishes to brush up on the hosiery business in Argentina, there is his information right at hand in the most convenient form imaginable. There seems to be no reason why some scheme of this sort would not be just as convenient and valuable for the chemical manufacturer.

However, there is a quarterly index that simplifies matters greatly for those who do not care to establish a file, especially if a set of bound volumes is maintained.

Annual reviews of the trade and commerce of the various countries are printed separately as supplements to Commerce Reports, one for each country. These vary in size according to the commercial importance of the country, but the contents are rather uniform, as the business conditions of the year are reviewed and statistical and other information is given as to domestic production and foreign trade. Special attention is given to the progress American goods make in the market, and the prospects for the future. These reviews are really up-to-date little commercial handbooks and are extremely valuable in reviewing current commercial progress in any country. The chemical trade of course receives its share of attention in countries where it is comparatively important.

\section{SPECIAL, REPORTS}

The Bureau issues a great many special reports, the majority of which are devoted to the markets for specified lines of goods in specified countries, or districts, although some are devoted to studies of basic economic conditions and some are on unusual but opportune subjects, of which Dr. Norton's reports on the dyestuff situation in this country and the census of dyestuff imports are examples.

The special reports on markets are written by consuls, commercial attachés, and traveling special agents, principally the last named. These traveling agents are specialists in certain lines, such as cotton goods, agricultural machinery, and shoes. Unfortunately, there has never been in the past a sufficient demand from the industry to warrant a special investigation of the foreign markets for American chemicals, but there is such a study on the program for Latin America for the present fiscal year and if sufficient interest is shown in that there will probably be others to follow. The pressure brought to bear on the Bureau for such investigations is the only index it has as to the attitude of the industry.

The catalog of the Bureau's publication will show what special publications of interest to the chemist have been published in the past, and announcements of new reports are printed in Commerce Reports.

\section{SUMMARY}

As already pointed out the foreign-trade information published by the Bureau of Foreign and Domestic Commerce can 
be approached at two different angles by the chemist. He may not be after practical results, as figured in dollars and cents. He may simply wish to keep abreast of the new expansion of the industry in which he is engaged, to know what is going on. A great many people are going to take that sort of interest in foreign trade in the future, just as the average Frenchman or Englishman keeps himself fairly well posted on foreign investment markets, whether he has any money invested abroad or not. We ought to take at least a cultural interest in the great industrial and commercial developments of the country.

But many chemists are going to look at the matter in a very practical manner. To lay a sure foundation for future success they must familiarize themselves with conditions in foreign fields. They must come to look upon business with Argentina, or China, or South Africa, as they now look upon business in the Pittsburgh territory, or the Chicago territory, or the New England territory. It really is not much different when you become accustomed to the longer focus.

The practical minded chemist will also find it necessary to study the facts of our own import trade if he is to make sture progress in his efforts to manufacture here at home the chemicals we formerly purchased abroad. The forthcoming census of imported chemicals is being made to the order of the American chemists.

As the chemists get along in their studies of the Bureau's data they will soon be able to make suggestions for additional service, and I can assure them that the sooner they come the better the Bureau will like it.

\section{THE METHOD OF PREPARATION OF THE CENSUS OF CHEMICAL IMPORTS}

By E. R. PICKRELL

Special Agent, Bureau of Foreign and Domestic Commerce

It was with pleasure that I accepted the invitation of Dr. Herty to state briefly for your information the method of preparation of the Census of Chemical Imports. As you gentlemen well know, the idea of this census was conceived by your fellow member, Dr. B. C. Hesse. Upon request of representatives of the AMERICAN CHEMrCaL, SOCretry, the Department of Commerce undertook for the benefit of American chemical manufacturers this monumental statistical work. The Census of Dyestuffs which was published in Igr 6 by the Bureau of Foreign and Domestic Commerce was the initial undertaking of this kind by any branch of the United States Government. How well Dr. Norton accomplished this vital and timely task is shown by the fact that requests for copies of the dyestuff census have been received even from foreign countries. To-day the domestic dyestuff manufacturers have at their disposal information concerning the importation of dyestuffs into the United States which is of inestimable value for the development of a permanent domestic dyestuff industry.

The Census of Chemical Imports is a much greater and more difficult task than the dyestuff census, for it entails the procurement of information relating to a vast and varied number of articles. The statistical dața presented by this census will be of value not only to chemical manufacturers but also to the drug manufacturers, synthetic medicinal manufacturers, perfumery manufacturers, paint and varnish industries, oil industries, and fertilizer industries.

During the fiscal year I9I3-I9I4, chemicals, allied chemicals, drugs, and medicinals imported into this country totaled in value $\$ 76,000,000$. This total was divided as follows:

Chemicals, drugs, dyes, and medicines........... \$95,000,000 Oils................................................ $4,46,000,000$

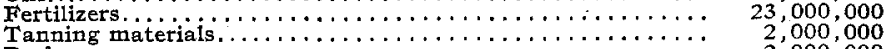

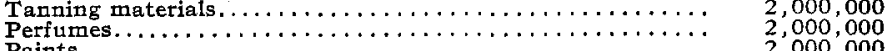

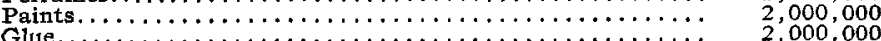

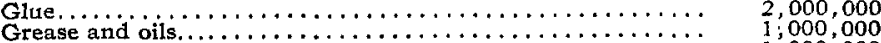

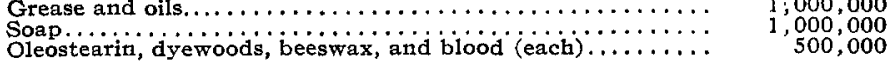

Inasmuch as the object of the Census of Chemical Imports was to show the quantity, value, country of origin, and per cent of the quantity imported from each foreign country of every chemical, drug, allied chemical, and medicinal imported into this country for the fiscal year I9I3-19I4, the last normal year, and since there was no available statistical data in this country setting forth this information, it was necessary to examine every invoice filed at the different customhouses in this country during that one fiscal year.

In view of the fact that more than sixty per cent of all the articles imported into the United States come through the Port of New York and that probably seventy-five per cent of all the chemicals imported are entered here, it was deemed advisable that the clerical staff engaged on the census personally examine the New York entries.

The original request was made to the Secretary of the Treasury that all invoices, some 700,000, received in the United States for the fiscal year I9I3-rgI4 be forwarded to the Port of New York for examination by the staff engaged on the census. That official was of the opinion this procedure wonld not be advisable because of the increased liability that some of these very valuable records might be lost or destroyed in transit. The alternative procedure was then adopted of sending circular letters of instruction, with an appended alphabetical list of 3500 chemicals, allied chemicals, drugs, and medicinals to the collectors of the headquarters ports of the forty-eight customs districts into which the United States and its territorial possessions are divided, requesting that invoices covering all these articles be forwarded to New York.

It is the aim of the census to amplify Schedule $\mathrm{E}$ of Imports, that is, Table 9 of the Commerce and Navigation Reports published by the Bureau of Foreign and Domestic Commerce, maintaining the same classification as closely as possible, but always keeping in mind that the purpose of the census is purely commercial. Consequently the commercial classification has had precedence over scientific terminology. It would have been a much easier task to have devised and employed a strict scientific classification and disregarded entirely Table 9, which follows more or less closely the Tariff Act of October 3, r913.

This amplification is to show the quantity, value, and per cent imported from a foreign country of every chemical, allied chemical, drug and medicinal imported into this country during the fiscal year prior to the European war. In other words, the seventy-five classes covering these articles provided for in basket clauses in Table 9 are to be amplified into over three thousand articles. By means of this amplification each article will be specifically designated instead of being grouped together, as formerly, in general terms or basket clauses. For example, Table 9 now provides for 32 acids by name. The Census of Chemical Imports will show more than 60 acids by name. Every acid imported into this country in the fiscal year 1913-I914 will be provided for in the census. This same table lists 2 I soda compounds. The census has already more than 52. There are an unlimited number of articles, many of which are of common chemical usage which will be provided for definitely in the census and which are at present hopelessly lost in the basket clauses. Table 9 does not show more than half a dozen synthetic medicinals; the census will show every synthetic medicinal imported during that year. Whereas in Table 9 medicinal compounds, preparations, and salts to a value in excess of $\$ 315,000$ were grouped together in one general class, the census will completely subdivide this class so that probably more than 150 different medicinal preparations will be shown. Then again, crude drugs valued at over $\$ 1,000,000$ were imported during the fiscal year 1913-19I4. These drugs, which were divided into two general classes in Table 9, will be completely separated into over 250 different articles.

To gather this tremendous amount of detailed information a staff of 24 clerks has been employed, some since March 1918, 